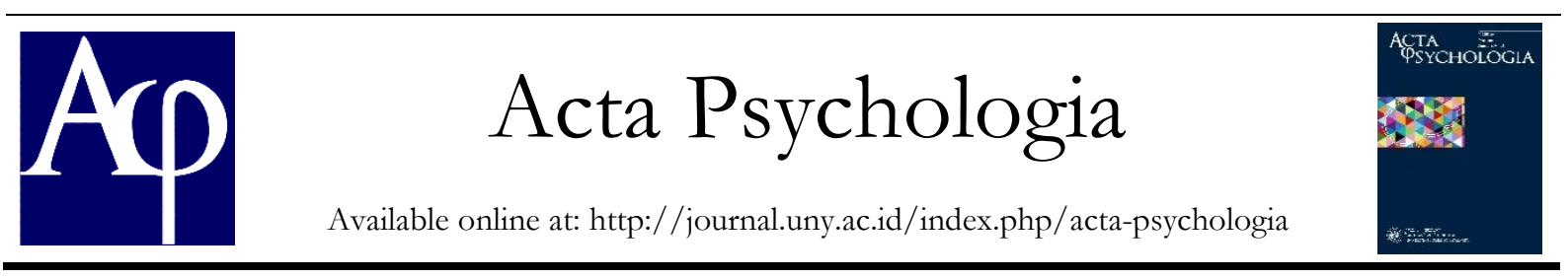

\title{
Pengaruh Self-efficacy Terhadap Komitmen Organisasi pada Karyawan The Rich Jogja Hotel
}

\author{
Nira Avie Dyah Puspita Dewi
}

Program Studi Psikologi, Universitas Negeri Yogyakarta; Jl. Colombo No. 1 Sleman Yogyakarta, 55281

niraavie@gmail.com

\begin{abstract}
Abstrak
Penelitian ini bertujuan untuk mengkaji mengenai pengaruh self-efficacy terhadap komitmen organisasi pada karyawan The Rich Jogja Hotel. Penelitian ini menggunakan pendekatan kuantitatif dan merupakan penelitian ex- post facto. Subjek yang terlibat pada penelitian ini merupakan karyawan tetap The Rich Jogja Hotel yang berjumlah 111 orang. Instrumen penelitian menggunakan Skala Komitmen Organisasi dan Skala Self-efficacy. Seleksi item dalam penelitian ini menggunakan Corrected Item Total Correlation dengan angka korelasi antara 0,273-0,829. Uji reliabilitias yang digunakan adalah uji Cronbach Alpha dengan hasil koefisiensi pada variabel komitmen organisasi sebesar 0,777 dan koefisiensi variabel self-efficacy sebesar 0,899 . Berdasarkan hasil analisis regresi sederhana, didapatkan hasil bahwa selfefficacy berpengaruh positif terhadap komitmen organisasi, dengan nilai $\mathrm{F}$ hitung $=28,134>\mathrm{F}$ tabel dengan nilai $\mathrm{R}^{2}=$ 0,205 atau $20,5 \%$.
\end{abstract}

Kata Kunci: selfefficacy, komitmen organisasi

\begin{abstract}
This research aims to study the influence of self-efficacy on the organizational commitment to employees of The Rich Jogja Hotel. This research uses a quantitative approach and is an ex-post facto research. The subject involved in this study was 111 permanent employee of The Rich Jogja Hotel. This research uses Organization Scale and Self-efficacy scale. The selection of items in this study uses Corrected Item Total Correlation with a correlation number between 0,273-0,829. The used reliability test was the Cronbach Alpha test with coefficiencies in the organizational commitment variable of 0.777 and the coefficiencies of the self-efficacy variable by 0.899 . Based on the results of a simple regression analysis, the results were obtained that self-efficacy positively affected the organizational commitments, with the value $\mathrm{F}$ count $=28.134>\mathrm{F}$ tables with a value of $\mathrm{R}^{2}=0.205$ or $20.5 \%$.
\end{abstract}

Keywords: self-efficacy, organizational commitment

\section{Pendahuluan}

Suatu perusahaan dapat dikatakan ideal, apabila perusahaan mampu memelihara, mengelola atau memanfaatkan sumber daya manusia sebagai suatu sumber daya yang sangat diperlukan dan dianggap sebagai aset perusahaan yang berharga (Suseno, 2012). Sumber daya manusia memiliki banyak peran penting dalam suatu organisasi atau perusahaan, oleh karena itu perusahaan menginginkan sumber daya manusia yang memiliki kualitas serta kapasitas yang baik agar mampu bersaing secara global. Salah satu aspek yang diinginkan perusahaan adalah karyawan memiliki komitmen organisasi yang baik. Komitmen organisasi sangat penting bagi perusahaan karena, perusahaan dapat melihat karyawan dari penerimaan dan kepercayaan terhadap organisasi, keinginan karyawan untuk mencapai tujuan 
organisasi, dan memiliki keinginan yang besar untuk bertahan di organisasi tersebut (Hunt \& Morgan, dalam Utaminingsih 2014).

Ketika karyawan memiliki komitmen organisasi yang baik berarti karyawan memiliki keyakinan kuat, penerimaan tujuan dan nilai-nilai perusahaan, adanya kesediaan dari karyawan untuk bekerja keras untuk perusahaan, dan adanya keinginan untuk mempertahankan keanggotaan dalam suatu perusahaan (Asih \& Dewi, 2017). Dengan adanya komitmen organisasi yang baik pada diri karyawan maka akan menghindarkan dari gejala-gejala pemogokan, penurunan tingkat absesinsi, intensi turnover dan ketidakpuasan kerja (Asih \& Dewi, 2017). Perusahaan akan berupaya untuk menciptakan suatu situasi yang dapat mendorong timbulnya rasa memiliki, loyalitas, dan rasa percaya terhadap perusahaan sehingga, diharapakan dengan upaya tersebut dapat meningkatkan komitmen organisasi yang dimiliki oleh setiap karyawan.

Menurut Mathis \& Jackson (dalam Utaminingsih, 2014), komitmen organisasi merupakan tingkat kepercayaan dan penerimaan dari individu terhadap tujuan organisasi dan keinginan untuk tetap berada dalam organisasi tersebut. Ketika karyawan memiliki komitmen organisasi yang tinggi akan memberikan pengaruh positif terhadap motivasinya ketika bekerja, dan pencapaian target di perusahaan. Selain itu, dengan memiliki komitmen organisasi maka karyawan akan bekerja penuh dedikasi dan akan memberikan tenaga serta tanggung jawab yang lebih untuk menyokong kesejahteraan dan keberhasilan perusahaan tempatnya bekerja.

Berdasarkan pendapat Allen \& Meyer (1990) komitmen organisasi merupakan sikap individu yang memperlihatkan adanya keterikatan individu terhadap organisasi, kelekatan emosi, identifikasi dan keterlibatan individu dengan organisasi serta keinginan untuk tetap menjadi anggota organisasi. Allen \& Meyer (1991) mengidentifikasi tiga komponen komitmen organisasi yang bersifat multi dimensional diantaranya yaitu komitmen afektif, komitmen berkelanjutan dan komitmen normatif. Komitmen afektif berkaitan dengan perasaan emosional terhadap perusahaan, komitmen berkelanjutan berkaitan dengan perspektif untung dan rugi jika meninggalkan perusaan, dan komitmen normatif berkaitan dengan kewajiban moral yang dimiliki oleh karyawan untuk bekerja di perusahaan.

Fakta di lapangan menunjukkan bahwa terdapat permasalahan yang berkaitan dengan komitmen organisasi yaitu adanya karyawan yang memiliki masa kerja tergolong singkat yaitu rata- rata selama 2 tahun. Hal ini dapat mengindikasikan bahwa karyawan The Rich Jogja Hotel memiliki komitmen organisasi yang rendah karena memiliki masa kerja yang cukup singkat. Dengan adanya masa kerja yang tergolong singkat tersebut menyebabkan intensi turnover pada perusahaan menjadi tinggi. Hal tersebut tentunya tidak diinginkan oleh suatu perusahaan karena dapat memberikan dampak yang buruk terhadap perusahaan.

Terdapat berbagai faktor yang dapat mempengaruhi komitmen organisasi, salah satunya adalah self-efficacy (Saraswati \& Prihatsanti, 2017). Self-efficacy menurut Bandura (1982), merupakan keyakinan individu mengenai kemampuan yang dimilikinya dalam menyelesaikan suatu pekerjaan tertentu. Komitmen organisasi pada karyawan akan terbangun dengan baik apabila dari individu sendiri memiliki selfefficacy yang baik pula. Hal ini didukung dengan hasil penelitian yang dilakukan oleh Subagyo (2014) yang menyatakan bahwa orang dengan self-efficacy tinggi cenderung tidak mudah putus asa jika menghadapi kesulitan-kesulitan pekerjaan. Bagaimanapun rumitnya tugas dan pekerjaan yang harus dilakukan, orang 
dengan self-efficacy tinggi akan cenderung termotivasi untuk dapat menyelesaikan, tidak ada motivasi untuk meninggalkan pekerjaan atau organisasinya hanya karena adanya kesulitan atau rintangan dalam menjalankan tugas dan pekerjaan.

Menurut Bandura (dalam Santosa, 2014), mendefinisikan bahwa self-efficacy merupakan kepercayaan individu akan keyakinan kemampuannya untuk melakukan tindakan yang diharapkan. Selfefficacy memiliki peran penting terhadap perilaku yang dihasilkan oleh individu, hal ini sejalan dengan pendapat yang dikemukakan oleh Bandura (dalam Abidin, Pongtuluran \& Maria, 2016) bahwa selfefficacy memiliki peran dalam proses pengaturan terhadap motivasi individu dalam pencapaian kinerja yang sudah ditetapkan. Dengan adanya self-efficacy yang baik pada diri individu tentu akan menciptakan motivasi dalam dirinya untuk menyelesaikan suatu pekerjaan dengan baik dan mencapai target yang telah ditetapkan sesuai dengan kemampuan dan kapasitasnya.

Seseorang yang memiliki self-efficacy sangat rendah akan mudah menyerah dalam melakukan tugasnya dan individu tidak akan melakukan upaya apapun untuk mengatasi hambatan yang ada, karena mereka percaya bahwa tindakan yang mereka lakukan tidak akan membawa pengaruh apapun. Hal ini sejalan dengan pendapat Schultz (Prestiana \& Purbandini, 2012), menyatakan bahwa seseorang yang memiliki self-efficacy rendah akan cenderung merasa helpless, tidak mampu melakukan pengaturan pada keadaan yang terjadi pada hidupnya. Dengan adanya sikap-sikap tersebut, maka individu akan merasa suatu pekerjaan menjadi sebuah ancaman dan sumber stres bagi individu (Jex, Blies \& Primeau, dalam Prestiana \& Purbandini 2012). Munculnya fenomena keinginan berpindah kerja atau Turnover Intention salah satunya dikarenakan oleh karyawan yang memiliki efikasi diri yang lemah (Rohmawati, 2018).
Individu yang memiliki self-efficacy baik akan mampu menetapkan suatu tujuan dan memelihara komitmen yang kuat terhadap tujuan tersebut. Hal ini didukung oleh hasil penelitian terdahulu yaitu salah satu penentu individu dapat melaksanakan tugas atau aktivitas tertentu sehingga dapat bertahan di suatu perusahaan adalah adanya self-efficacy (Asih \& Dewi, 2017). Dari hasil penelitian tersebut menunjukkan bahwa adanya pengaruh positif antara SelfEfficacy terhadap komitmen organisasi (Asih \& Dewi, 2017).

Penelitian ini memfokuskan hubungan self-efficacy dengan komitmen organisasi yang dimiliki oleh karyawan. Penelitian ini menarik dan penting untuk diteliti dikarenakan analisis komitmen organisasi pada karyawan dilakukan dengan menggunakan faktor kepribadian yang dimiliki oleh masing-masing karyawan yaitu self- efficacy dan bukan bergantung pada potensi- potensi atau faktor-faktor organisasi seperti gaji, kompensasi, fasilitas, lingkungan perusahaan dan lain-lain.

Berdasarkan uraian di atas, maka permasalahan dan tujuan dari penelitian ini adalah untuk mengetahui pengaruh dari selfefficacy terhadap tingkat komitmen organisasi yang dimiliki oleh karyawan The Rich Jogja Hotel. Adapun manfaat dari penelitian ini yaitu untuk memperkaya kajian mengenai self-efficacy dan komitmen organisasi karyawan, baik untuk perusahaan, karyawan, peneliti selanjutnya, maupun para pembaca.

\section{Metode Penelitian}

Metode penelitian ini menggunakan pendekatan kuantitif dengan jenis penelitian yang digunakan yaitu ex-post facto. Penelitian Ex-post Facto bertujuan untuk menemukan penyebab yang memungkinkan terjadinya perubahan perilaku, gejala atau fenomena yang disebabkan oleh suatu peristiwa, fenomena, perilaku atau hal-hal yang menyebabkan perubahan pada variabel bebas. 
Penelitian ini dilakukan di The Rich Jogja Hotel yang berlokasi di Jl Magelang No.19 KM.6, Kutu Patran, Sinduadi, Mlati, Sleman, Daerah Istimewa Yogyakarta. Waktu penulisan penelitian ini terhitung mulai Oktober 2019 sampai dengan bulan Mei 2020. Pengambilan data penelitian dilakukan pada bulan Januari 2020. Penelitian ini selesai ditulis pada tanggal 18 Juni 2020.

Populasi pada penelitian ini adalah karyawan tetap di Hotel Rich Jogja. Adapun jumlah karyawan tetap yang bekerja di The Rich Jogja Hotel yaitu sejumlah 190 karyawan. Pada penelitian ini, pengambilan sampel menggunakan teknik Simple Random Sampling yaitu pengambilan sampel yang diambil secara acak tanpa memperhatikan tingkatan yang ada dalam populasi, tiap elemen populasi memiliki peluang yang sama dan diketahui untuk terpilih menjadi subjek (Noor, 2011). Penentuan jumlah sampel pada penelitian ini berdasarkan rumus dari Krejcie \& Morgan. Berdasarkan hasil perhitungan menggunakan rumus dari Krejcie \& Morgan didapatkan sampel penelitian ini yaitu sebanyak 128 orang.

Penelitian ini terdiri dari beberapa tahap. Tahap pertama yaitu melakukan pengambilan data dengan membagikan instrumen penelitian (skala komitmen organisasi dan skala self-efficacy) kepada 128 orang karyawan The Rich Jogja Hotel yang diedarkan secara acak atau random. Tahap selanjutnya adalah melakukan seleksi item dan uji reliabilitas terhadap data instrumen yang telah diisi oleh subjek penelitian sebanyak 111 orang.

Seleksi item dilakukan dengan menggunakan bantuan program SPSS kemudian dapat dilihat dari hasil outputnya yaitu pada tabel Item-total Statistics pada kolom corrected item-total correlation dengan memperhatikan kriteria nilai corrected item-total correlation yaitu $<0,3$ (Azwar, 2012). Jika banyak item yang gugur dengan kriteria $<0,3$ maka dapat diturunkan kriterianya menjadi 0,275 dan jika ternyata masih banyak item yang gugur maka dapat diturunkan lagi sampai <0,25 (Azwar, 2012). Pada penelitian ini kriteria nilai corrected item-total correlation diturunkan menjadi $<0,25$. Tahap selanjutnya yaitu melakukan uji reliabilitas yang menggunakan bantuan program SPSS yaitu dengan analisis Cronbach's Alpha. Hasil uji reliabilitas didapatkan koefisien komitmen organisasi sebesar 0,777 dan koefisien selfefficacy sebesar 0,899.

Data pada penelitian ini merupakan data primer yang diperoleh secara langsung melalui pengisian instrumen penelitian yang diedarkan oleh peneliti kepada karyawan The Rich Jogja Hotel. Adapun instrumen yang digunakan pada penelitian ini yaitu skala komitmen organisasi dan skala selfefficacy. Skala komitmen organisasi terdiri dari 24 item dan skala self-efficacy terdiri dari 24 item. Seluruh subjek mengisi instrumen yang telah diedarkan dalam kurun waktu kurang lebih selama 1 minggu, kemudian instrumen tersebut di kembalikan kepada peneliti.

Analisis data pada penelitian ini menggunakan analisis statistik. Analisis statistik yang digunakan diantaranya yaitu:

1. Analisis Deskriptif

Analisis ini digunakan untuk menjelaskan mengenai karakteristik data dan/atau ukuran pemusatan dari gambar penelitian yang meliputi analisis deskriptif karakteristik subjek dan analisis deskriptif kategori variabel.

2. Uji Prasyarat Analisis

Uji prasyarat analisis dilakukan karena sebagai prasayrat untuk melakukan uji hipotesis menggunakan analisis regresi. Uji prasayarat pada penelitian ini meliputi uji normalitas dan uji linieritas. Uji linieritas dan uji normalitas menggunakan program SPSS, sementara uji normalitas menggunakan formula Kolmogorov-Smirnov.

3. Uji Hipotesis

Uji hipotesis pada penelitian ini menggunakan analisis regresi linier 
sederhana dengan bantuan program SPSS.

\section{Hasil Penelitian dan Pembahasan}

Berdasarkan hasil analisis deskriptif karakteristik subjek, diperoleh hasil sebagai berikut:

Tabel 1. Frekuensi Karakteristik Jenis Kelamin

\begin{tabular}{lcl}
\hline $\begin{array}{c}\text { Jenis } \\
\text { Kelamin }\end{array}$ & Frekuensi & Presentase \\
\hline Laki-laki & 84 & $75,7 \%$ \\
\hline Perempuan & 27 & $24,3 \%$ \\
\hline Total & 111 & $100 \%$ \\
\hline
\end{tabular}

Tabel 2. Frekuensi Karakteristik Usia

\begin{tabular}{lcl}
\hline \multicolumn{1}{c}{ Usia } & Frekuensi & Presentase \\
\hline$<20$ tahun & 14 & $12,6 \%$ \\
\hline $20-25$ tahun & 59 & $53,2 \%$ \\
\hline $26-30$ tahun & 28 & $25,2 \%$ \\
\hline $31-35$ tahun & 7 & $6,3 \%$ \\
\hline$>35$ tahun & 3 & $2,7 \%$ \\
\hline Total & 111 & $100 \%$ \\
\hline
\end{tabular}

Tabel 3. Frekuensi Pendidikan Terakhir

\begin{tabular}{lcc}
\hline \multicolumn{1}{c}{ Usia } & Frekuensi & Presentase \\
\hline SMA & 35 & $31,5 \%$ \\
\hline SMK & 51 & $45,9 \%$ \\
\hline STM & 4 & $3,6 \%$ \\
\hline D1 & 7 & $6,3 \%$ \\
\hline D3 & 5 & $4,5 \%$ \\
\hline S1 & 9 & $8,1 \%$ \\
\hline Total & 111 & $100 \%$ \\
\hline
\end{tabular}

Tabel 4. Frekuensi Karakteristik Departemen

\begin{tabular}{lcc}
\hline Departemen & Frekuensi & Presentase \\
\hline House Keeping & 22 & $19,8 \%$ \\
\hline Front Office & 21 & $18,9 \%$ \\
\hline $\begin{array}{l}\text { Food and } \\
\text { Beverages } \\
\text { Attendant }\end{array}$ & 32 & $28,8 \%$ \\
\hline Engineering & 21 & $18,9 \%$ \\
\hline Security & 15 & $13,5 \%$ \\
\hline Total & 111 & $100 \%$ \\
\hline
\end{tabular}

Tabel 5. Frekuensi Karakteristik Masa Kerja

\begin{tabular}{lcc}
\hline Lama Kerja & Frekuensi & Presentase \\
\hline$<2$ tahun & 40 & $36 \%$ \\
\hline $2-4$ tahun & 51 & $45,9 \%$ \\
\hline $5-7$ tahun & 18 & $16,2 \%$ \\
\hline$>7$ tahun & 2 & $1,8 \%$ \\
\hline Total & 111 & $100 \%$ \\
\hline
\end{tabular}

Berdasarkan hasil analisis deskriptif kategori variabel diperoleh data sebagai berikut:

1) Komitmen organisasi memiliki rerata (mean) yaitu sebesar 45 dan standar deviasi sebesar 10, sehingga kategorisasi yang dihasilkan sebagai berikut:

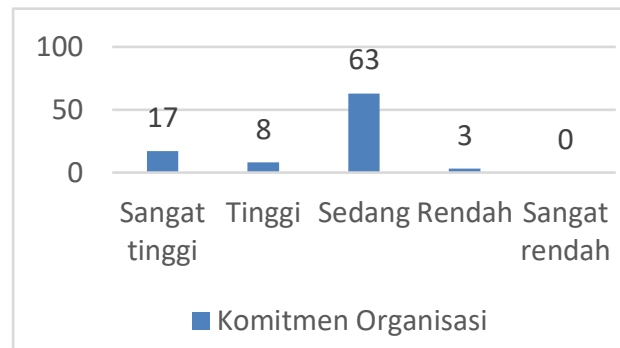

Gambar 1. Kategorisasi Komitmen Organisasi

a. Komitmen afektif memiliki rerata (mean) yaitu sebesar 18 dan standar deviasi sebesar 4, sehingga kategorisasi yang dihasilkan sebagai berikut: 


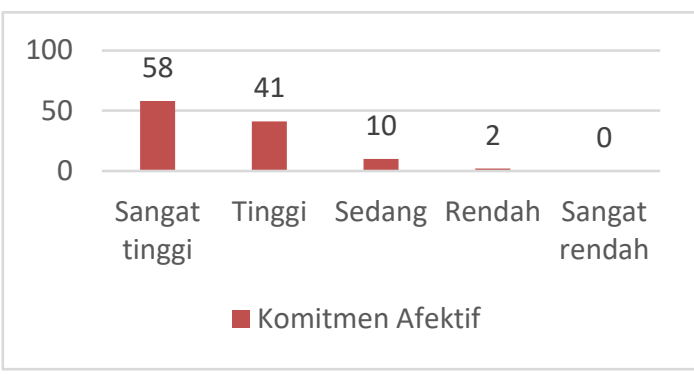

Gambar 2. Kategorisasi Komitmen Afektif Organisasi

b. Komitmen berkelanjutan memiliki rerata yaitu sebesar 12 dan standar deviasi sebesar 2,67, sehingga dapat dikategorisasikan yaitu sebagai berikut:

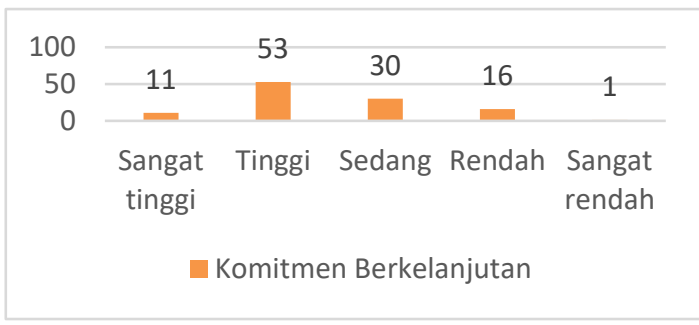

Gambar 3. Kategorisasi Komitmen Berkelanjutan

c. Komitmen normatif memiliki rerata (mean) yaitu sebesar 15 dan standar deviasi sebesar 3,33, sehingga dapat dikategorisasikan yaitu sebagai berikut :

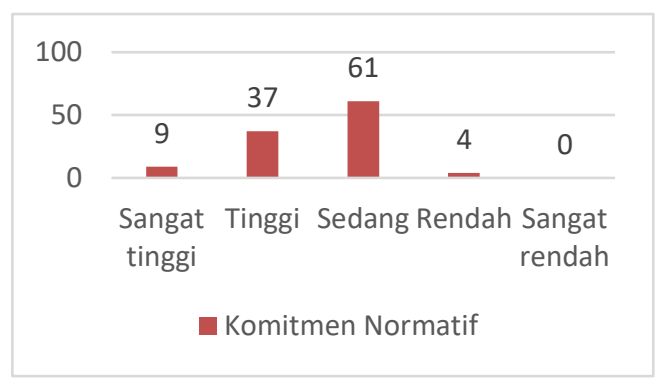
Gambar 4. Kategorisasi Komitmen
Berkelanjutan

2) Self-efficacy memiliki rerata (mean) yaitu sebesar 66 dan standar deviasi sebesar 14,67, sehingga dapat dikategorisasikan yaitu sebagai berikut:

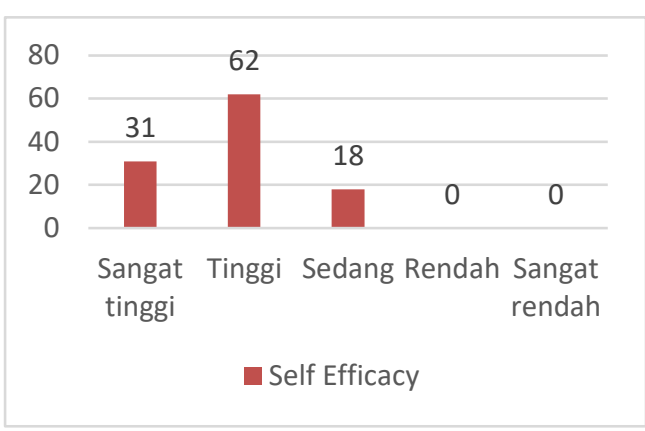

Gambar 5. Kategorisasi Selfefficacy

Selain melakukan kategorisasi pada sampel, dilakukan juga uji prasyarat analisis yang berupa uji normalitas, dan uji linearitas.

Dari hasil uji normalitas pada tabel 6 dapat dikatakan bahwa data yang diperoleh dari pengisian skala self-efficacy dan komitmen organisasi berdistribusi normal. Hal ini dapat dilihat pada nilai Asymp. Sig. $(2$-tailed $)=0,710$, sehingga $\mathrm{p}>\alpha$ atau nilai signifikansi lebih dari 0,05. Dengan demikian, uji normalitas terpenuhi.

Tabel 6. Uji Normalitas

\begin{tabular}{llr}
\hline & & $\begin{array}{c}\text { Unstandar } \\
\text { dized } \\
\text { Residual }\end{array}$ \\
\hline $\mathrm{N}$ & & 111 \\
\hline & Mean & $0 \mathrm{E}-7$ \\
\hline Normal Parametersa,b & Std. & 5,314749 \\
\cline { 2 - 3 } & Deviation & 83 \\
\cline { 2 - 3 } & Absolute &, 067 \\
\hline Most Extreme & Positive &, 050 \\
\cline { 2 - 3 } Differences & & \\
\cline { 2 - 3 } & Negative &,- 067 \\
\hline Kolmogorov- & &, 701 \\
Smirnov Z & &, 710 \\
\hline Asymp. Sig. (2-tailed) & & \\
\hline
\end{tabular}

Berdasarkan hasil uji linieritas didapatkan nilai Deviation from Linearity Sig adalah 0,143 lebih besar dari 0,05 atau F hitung sebesar 1,332 lebih kecil dari F tabel sebesar 1,5. Dengan demikian dapat dikatakan bahwa ada hubungan linier secara signifikan antara variabel self-efficacy dengan komitmen organisasi.

Setelah melakukan uji prasayarat analisis, dilakukan uji hipotesis. 
Berdasarkan tabel rangkuman hasil analisis regresi linier sederhana di atas, diperoleh nilai $\mathrm{F}$ hitung sebesar 28,134 yang lebih besar dari $F$ tabel sebesar 3,92 dengan signifikansi (sig.) sebesar 0,000 $<0,05$ dan nilai koefisien regresi positif, sehingga dapat dikatakan bahwa variabel self-efficacy berpengaruh positif terhadap variabel komitmen organisasi dengan nilai R2 atau kontribusi dalam mempengaruhi sebesar 0,205 atau 20,5\%. Hal tersebut berarti ketika self-efficacy meningkat, maka akan terjadi peningkatan pula pada komitmen organisasi yang dimiliki oleh karyawan, sehingga hipotesis penelitian yang diajukan oleh peneliti diterima.

Tabel 7. Rangkuman Hasil Analisis Regresi Linier Sederhana

\begin{tabular}{clccc}
\hline $\begin{array}{c}\text { Koefisien } \\
\text { Regresi }\end{array}$ & $\mathrm{R}$ & $\mathrm{R}^{2}$ & $\begin{array}{c}\mathrm{F} \\
\text { hitung }\end{array}$ & Sig. \\
\hline 0,299 & 0,453 & $0,20528,134$ & 0,000 \\
\hline
\end{tabular}

Komponen komitmen organisasi bersifat multi dimensi, sehingga peneliti melakukan analisis tambahan dari masingmasing komponen dari komitmen organisasi yang dapat di lihat dari tabel rangkuman berikut ini :

Tabel 8. Rangkuman Analisis Komponen Komitmen Organisasi

\begin{tabular}{lclc}
\hline \multicolumn{1}{c}{ Variabel } & $\mathrm{R}^{2}$ & $\mathrm{~F}$ hitung & Sig. \\
\hline $\begin{array}{l}\text { Komitmen } \\
\text { afektif }\end{array}$ & 0.260 & 38,278 & 0,000 \\
\hline $\begin{array}{l}\text { Komitmen } \\
\text { berkelanjutan }\end{array}$ & 0,038 & 4,344 & 0,039 \\
\hline $\begin{array}{l}\text { Komitmen } \\
\text { Normatif }\end{array}$ & 0,085 & 10,061 & 0,002 \\
\hline
\end{tabular}

Dari hasil beberapa analisis yang telah dilakukan pada penelitian ini, diantaranya yaitu analisis deskriptif, uji prasyarat analisis, dan uji hipotesis membuktikan hasil bahwa self-efficacy memberikan pengaruh positif terhadap komitmen organisasi pada karyawan di The Rich Jogja Hotel. Dengan demikian dapat dikatakan bahwa ketika self-efficacy meningkat maka terjadi peningkatan pula pada tingkat komitmen organisasi yang dimiliki oleh karyawan.

Setelah analisis uji hipotesis menggunakan regresi linier sederhana didapatkan hasil bahwa self-efficacy memberikan pengaruh terhadap komitmen organisasi. Hal ini dapat dilihat dari nilai $\mathrm{F}$ hitung sebesar 28,134 yang lebih besar dari F tabel sebesar 3,92 dengan signifikansi (sig.) sebesar $0,000<0,05$ dan nilai koefisien regresi positif, sehingga dapat dikatakan bahwa variabel self-efficacy berpengaruh positif terhadap variabel komitmen organisasi dengan nilai $\mathrm{R} 2$ atau kontribusi dalam mempengaruhi sebesar 0,205 atau $20,5 \%$.

$$
\text { Hasil uji analisis tambahan }
$$

per komponen komitmen organisasi menunjukkan tingkat komitmen afektif yang dimiliki oleh sebagian besar subjek pada penelitian ini tergolong sangat tinggi dengan frekuensi yang didapatkan sebanyak 58 karyawan atau 52,3\%. Selain itu sumbangan self-efficacy dalam mempengaruhi komitmen afektif sebesar 2,6\%. Menurut Gellatly, Meyer \& Luchak (dalam Suseno, 2012) mengungkapkan bahwa karyawan memiliki komitmen afektif yang tinggi akan memiliki sikap positif terhadap perusahaan, mau dan mampu terlibat secara aktif di persahaan dan mempunyai keterikatan sosial dengan anggota perusahaan.

Dalam hal ini sesuai dengan hasil penelitian yaitu setiap ada kegiatan yang diadakan oleh perusahaan seperti Staff Gathering, karyawan selalu berpartisipasi pada acara tersebut. Tujuan kegiatan tersebut diselenggarakan oleh Human Resoure Departement adalah untuk mengakrabkan karyawan yang ada di Rich Jogja Hotel. Sejalan dengan pendapat Meyer \& Allen (1991) yang mengatakan bahwa, komitmen afektif menekankan pada keterikatan individu secara emosional 
terhadap organisasinya. Keterikatan emosional tersebut dibentuk melalui kegiatan-kegiatan yang telah diselenggarakan oleh Human Resource Departement untuk menciptakan atmosfer kekeluargaan pada seluruh karyawan yang bekerja di The Rich Jogja Hotel, sehingga karyawan memiliki komitmen afektif atau keterikatan emosional pada perusahaan tergolong sangat tinggi.

Tingkat komitmen keberlanjutan mayoritas pada subjek penelitian ini tergolong tinggi dengan sebanyak 53 orang atau setara dengan $47,7 \%$. Selain itu sumbangan self-efficacy dalam mempengaruhi komitmen keberlanjutan sebesar 3,8\%. Menurut Meyer dan Allen (1991) komitmen berkelanjutan yaitu keinginan individu untuk tetap bekerja di organisasi dengan waktu yang lama dan akan merasa rugi apabila meninggalkan perusahaan tersebut. Subjek yang bekerja pada The Rich Jogja Hotel mayoritas memiliki masa kerja ratarata 2- 4 tahun. Dari masa kerja tersebut subjek merasa sudah menjadi bagian dari perusahaan sehingga akan merasa rugi apabila meninggalkan tempatnya bekerja. Hal ini didukung oleh pendapat Khaerul Umam (dalam Parinding, 2017) yang menyatakan bahwa kerugian dapat berupa kerugian investasi yang didalamnya meliputi waktu maupun usaha yang harus dilepaskan oleh karyawan jika meninggalkan perusahaan.

Dari hasil uji analisis tambahan per komponen menunjukkan bahwa subjek pada penelitian ini memiliki tingkat komitmen normatif yang tergolong sedang yaitu sebanyak 61 karyawan atau 55,0\%. Selain itu sumbangan self-efficacy dalam mempengaruhi komitmen normatif sebesar 8,5\%. Menurut Meyer dan Allen (1991), komitmen normatif diartikan sebagai suatu perasaan wajib dari individu atau karyawan untuk bertahan dalam suatu organisasi atau perusahaan. Komitmen normatif yang ada dalam diri karyawan disebabkan oleh kewajiban-kewajiban pekerjaan karyawan terhadap organisasi atau perusahaan
(Dwiarta dalam Sukamto, Junarto, Kaihatu \& Kartika, 2014). Dalam hal ini berdasarkan hasil penelitian terdapat salah satu karyawan yang mengatakan jika sudah sepenuhnya memiliki tanggung jawab dengan pekerjaan yang ada. Hal ini dapat dilihat ketika karyawan yang bersangkutan tidak masuk kerja kemudian karyawan tersebut merasa meninggalkan kewajibannya di perusahaan.

Dari hasil analisis diskriptif menunjukkan bahwa sebagian besar subjek penelitian memiliki tingkat self-efficacy yang tergolong tinggi yaitu sebanyak 62 karyawan dengan presentase $55,9 \%$. Self-efficacy merupakan keyakinan individu mengenai kemampuan dirinya dalam melakukan tugas atau tindakan yang diperlukan untuk mencapai hasil tertentu (Bandura dalam Prestina \& Purbandini, 2012). Berdasarkan gambaran objek penelitian yang telah dipaparkan, Human Resource Department mengadakan training yang diadakan sebulan $4 \mathrm{x}$ di setiap departement yang ada di The Rich Jogja Hotel. Kegiatan tersebut merupakan salah satu upaya yang dilakukan oleh Human Resource Departement untuk meningkatkan kualitas serta kapasitas karyawan yang bekerja di The Rich Jogja Hotel. Selain itu, dengan diadakannya training, karyawan akan mampu mengerjakan setiap pekerjaan yang ada di bidangnya dan dapat meminimalisir ketidakmampuan dalam menyelesaikan suatu pekerjaan.

Self-efficacy dapat memberikan pengaruh atau kontribusi terhadap komitmen afektif karena salah satu proses terbentuknya self-efficacy melalui proses afektif. Proses afektif ini berkaitan dengan situasi serta reaksi emosional yang dapat mempengaruhi tindakan baik secara langsung maupun tidak langsung (Bandura, dalam Ismail 2016). Menurut Bandura (dalam Ismail 2016), individu yang memiliki self-efficacy yang baik, akan memusatkan perhatian dan usahanya kepada kebutuhan situasi, serta percaya bahwa individu tersebut mampu mengatasi situasi yang mengancam, sehingga tidak akan merasa 
cemas atau terganggu dengan ancaman atau hambatan yang ditemui. Dengan demikian individu akan mau bekerja keras untuk perusahaan dan memiliki keyakinan diri yang baik, sehingga individu memiliki komitmen afektif yang baik yaitu dengan ditunjukannya sikap yang positif terhadap perusahaan, dan mampu terlibat aktif di perusahaan.

Individu yang memiliki self-efficacy akan ditunjukkan dengan kepercayaan diri serta keyakinan diri terhadap penyelesaian tugas-tugasnya. Selain itu menurut Bandura (Prestina \& Purbandini, 2012) mengatakan bahwa individu dengan self-efficacy yang baik akan memiliki semangat atau optimisme yang lebih tinggi di dalam menjalankan suatu tugas tertentu. Dengan demikian, ketika individu memiliki keyakinan terhadap kemampuannya serta mampu menghadapi dan memecahkan permasalahan yang dihadapinya ketika bekerja, maka individu akan mengembangkan sikap-sikap positif seperti percaya diri dan berkomitmen pada perusahaan, sehingga individu akan mau bekerja dan tetap berada di perusahaan tersebut. Hal ini mempengaruhi komitmen berkelanjutan yaitu ketika individu memiliki self-efficacy yang baik maka, individu akan terus bekerja di perusahaan dalam jangka waktu yang lama dan akan menciptakan kerugian apabila meninggalkan perusahaan karena telah memberikan kontribusinya kepada perusahaan dalam waktu yang lama.

Komitmen normatif berkaitan dengan perasaan karyawan mengenai kewajiban yang harus diberikan kepada perusahaan (Sukamto, Junarto, Kaihatu \& Kartika, 2014). Ketika karyawan The Rich Jogja memiliki komitmen normatif yang baik maka karyawan akan merasa memang seharusnya tetap bekerja pada perusahaan tempat bekerjanya saat ini. Individu dengan self-efficacy yang baik akan menunjukkan keyakinan dan kemampuannya dalam menyelesaikan pekerjaan. Dengan demikian, individu akan dituntut untuk dapat mengatasi permasalahan dan pekerjaan yang sedang dihadapinya. Hal ini akan membuat individu merasa memiliki kewajiban dan tanggung jawab untuk tetap bekerja di perusahaan tempatnya bekerja.

Berdasarkan analisis yang telah dilakukan, hasil analisis berbeda dari survei awal atau pra penelitian. Hal ini dikarenakan pada pra penelitian, peneliti mendapatkan sumber data dalam bentuk generalisasi atau perhitungan secara mayoritas mengenai intensi turnover. Berdasarkan hasil data tersebut, terdapat karyawan yang memiliki masa kerja yang tergolong singkat yaitu kurang lebih hanya 2 tahun. Hal ini dapat mengindikasikan bahwa karyawan The Rich Jogja Hotel memiliki komitmen organisasi yang rendah karena memiliki masa kerja yang cukup singkat.

Namun, pada hasil analisis didapatkan bahwa komitmen organisasi yang dimiliki oleh karyawan The Rich Jogja Hotel mayoritas tergolong sedang. Hal ini dikarenakan subjek yang berpartisipasi pada penelitian ini mayoritas berusia antara 20-25 tahun yang menandakan usia siap kerja, sementara karyawan yang memiliki masa kerja tergolong singkat tersebut merupakan karyawan yang usianya dibawah 20 tahun atau rata-rata merupakan siayang baru saja lulus dari Sekolah Menengah Atas dan sederajat yang memiliki keinginan berpindah tempat kerja untuk mencari pengalaman kerja. Hal ini tentunya berpengaruh terhadap tingkat komitmen organisasi yang dilihat dari masa kerjanya.

\section{Simpulan dan Saran}

Berdasarkan hasil dari analisis data diantaranya yaitu analisis deskriptif, uji prasyarat, dan uji hipotesis terhadap variabel-variabel pada penelitian ini yang mencakup self-efficacy sebagai variabel independen, dan komitmen organisasi sebagai variabel dependen, maka dapat ditarik kesimpulan sebagai berikut :

Variabel self-efficacy terbukti memberikan pengaruh positif terhadap komitmen organisasi pada karyawan The Rich Jogja Hotel. Hal ini dapat dibuktikan 
dengan hasil analisis regresi linier sederhana pada nilai $\mathrm{F}$ hitung sebesar 28,134 lebih besar dari F tabel yaitu sebesar 3,92 dengan signifikansi (sig.) sebesar 0,00 lebih kecil dari probabilitas 0,05 , sehingga dapat dikatakan self-efficacy berpengaruh terhadap komitmen organisasi.

Selain itu didapatkan nilai determinasi (R2) sebesar 0,205, maka selfefficacy memberikan kontribusi atau sumbangan dalam mempengaruhi komitmen organisasi sebesar 20,5\%. Analisis data menghasilkan koefisiensi regresi positif, sehingga dapat dikatakan ketika self-efficacy meningkat maka komitmen organisasi yang dimiliki oleh karyawan The Rich Jogja Hotel juga meningkat. Adapun Hasil persamaan garis regresi yang diperoleh yaitu : $\mathrm{Y}=$ 25,694+0,299 X.

Berdasarkan hasil penelitian, pembahasan dan kesimpulan yang diperoleh, maka saran yang dapat diberikan adalah sebagai berikut :

1. Bagi Perusahaan

Berdasarkan hasil penelitian yang telah dilakukan, saran yang dapat diberikan kepada The Rich Jogja Hotel adalah dengan terus berupaya meningkatkan self-efficacy yang dimiliki oleh karyawan dengan cara terus melakukan kegiatan training setiap bulannya. Training ini merupakan kegiatan yang dapat meningkatkan kemampuan atau skill yang dimiliki oleh karyawan sesuai dengan bidang yang dikerjakannya, dengan demikan ketika karyawan memiliki self-efficacy tergolong baik yang dicerminkan dengan keyakinan terhadap kemampuan yang dimiliki, diharapkan dapat memberikan kontribusi dalam meningkatkan komitmen organisasi yang pada karyawan The Rich Jogja Hotel.

2. Bagi Karyawan

Tingkat komitmen organisasi yang dimiliki oleh karyawan The Rich Jogja Hotel tergolong sedang. Maka dari itu, perlu adanya peningkatan komitmen organisasi pada karyawan agar perusahaan memiliki sumber daya manusia yang dapat bersaing dan lebih kompetitif karena karyawan yang berkomitmen tinggi biasanya kreatif dan inovatif. Upaya yang dapat dilakukan untuk meningkatkan komitmen organisasi adalah bersedia terlibat atau berpartisipasi, dan berusaha sebaik mungkin dalam aktivitas kerja organisasi (Halimsetiono, 2014).

3. Bagi Peneliti Selanjutnya

Peneliti selanjutnya dapat menganalisis factor-faktor lain yang memberikan kontribusi terhadap komitmen organisasi, seperti kepuasan kerja, motivasi, beban kerja dan lain sebagainya yang dapat memberikan pengaruh tingkat komitmen organisasi yang dimiliki oleh karyawan. Penelitian ini dapat dijadikan sebagai referensi untuk penelitian mengenai pengaruh selfefficacy terhadap komitmenorganisasi. Pengkajiansecara lebih mendalam diharapkan bisa dilakukan agar dapat memperoleh gambaran yang lebih lengkap dan menjadikan penelitian selanjutnya lebih baik dari penelitian ini

\section{Daftar Pustaka}

Abidin, M. I. Z., Pongtuluran, Y., \& Maria, S. (2017). Pengaruh kepuasan kerja, lingkungan kerja dan efikasi diri terhadap komitmen organisasi di rumah sakit smc samarinda. Akuntabel, 13(1), 1-10.

Allen, N. J., \& Meyer, J. P. (1997). Commitment in the workplace (theory, research and application). Sage Publication London.

Asih, G. Y., \& Dewi, R. (2017). Komitmen karyawan ditinjau dari self-efficacy dan persepsi dukungan organisasi di CV. 
Wahyu Jaya Semarang. Jurnal Dinamika Sosial Budaya, 19(1), 35 39.

Azwar, S. (2011). Penyusunan skala psikologis (Edisi 2). Yogyakarta: Pustaka Pelajar.

Bandura, A. (1982). Self-efficacy mechanism in human agency. American psychologist, 37(2), 122.

Halimsetiono, E. (2014). Peningkatan komitmen organisasi untuk menurunkan angka turnover karyawan. Kesmas: National Public Health Journal, 8(8), 339-345.

Ismail, I. (2016). Peran self-efficacy dalam meningkatkan kinerja Koperasi Indonesia. Jurnal Manajemen Bisnis Indonesia, 4, 35-50.

Meyer, J. P., Allen, N. J., \& Smith, C. A. (1993). Commitment to organizations and occupations: Extension and test of a threecomponent conceptualization. Journal of applied psychology, 78(4), 538.

Parinding, R. G. (2017). Analisis pengaruh komitmen afektif, komitmen berkelanjutan, dan komitmen normatif terhadap kinerja karyawan pada PT. Pegadaian (persero) cabang Ketapang. Magistra: Jurnal Ilmu Manajemen, 1(2), 88-107.

Prestiana, N. D. I., \& Purbandini, D. (2012). Hubungan antara efikasi diri (self efficacy) dan stres kerja dengan kejenuhan kerja (burnout) pada perawat IGD dan ICU RSUD Kota Bekasi. SOUL: Jurnal Ilmiah Psikologi, 5(2), 1-14.

Rohmawati, E. (2018). Analisis pengaruh efikasi diri terhadap keinginan berpindah kerja dengan kepuasan kerja sebagai variabel pemediasi. Jurnal
Akuntansi dan Manajemen, 15(1), 36-60

Santosa, S. B. (2014). Pengaruh efikasi diri (self-efficacy) dan prestasi belajar kewirausahaan terhadap motivasi berwirausaha berbasis teknologi (tecnopreneurship) siswa program keahlian teknik pemesinan Kelas XI SMK Muhammadiyah 3 Yogyakarta. Jurnal Pendidikan Vokasional Teknik. Mesin, 2(1), 37-44.

Saraswati, N. K., \& Prihatsanti, U. (2017). Hubungan antara selfefficacy dengan intensi turnover pada karyawan PT. Indonesia Taroko Textile Purwakarta. Empati, 6(1), 307-311.

Subagyo, A. (2014). Pengaruh lingkungan kerja dan self-efficacy terhadap komitmen organisasional dosen Politeknik Negeri Semarang. Orbith: Majalab Imiah Pengembangan Rekayasa dan Sosial, 10(1).

Sukamto, H., Junarto, Y., Kaihatu, T. S., et al. (2014). Analisa pengaruh komitmen afektif, komitmen normatif, dan komitmen berkelanjutan terhadap turnover intention di Dragon Star Surabaya. Jurnal Hospitality dan Manajemen Jasa, 2(2), 466-478.

Suseno, M. N. M. (2012). Motivasi spiritual dan komitmen afektif pada karyawan. Jurnal Psikologi, 5(1), 31-43.

Utaminingsih, A. (2014). Perilaku organisasi. Malang: UB Press. 
Badan Pusat Statistik

(BPS)

diakses dari http:www.bps.go.id/, diakses pada tanggal 20 Mei 2019

Barberis, N., Cernaro, V., Costa, S., Montalto, G., Lucisano, S., Larcan, R., \& Buemi, M. (2017). The relationship between coping, emotion regulation, and quality of life of patients on dialysis. International Journal of Psychiatry in Medicine, 52(2), 111123. https://doi.org/10.1177/009121741 7720893

Barcik, N. Emotion control and its impact on the disease acceptance in hemodialysis patients. (2015). Journal of Public Health, Nursing, and Medical Rescue No.7/2015 (44-64barcik)

Barcik, N., \& Babiarczyk, B. (2017). Emotion control and its impact on the disease acceptance in hemodialysis patients. Journal of Public Health, Nursing and Medical Rescue, 3(3), 23-29.

Bayoumi, Magda. (2011). Identification of The Needs Of Hemodialysis Patients Using

The Concept Of Maslow's Hierarchy of Needs. College of Health Science, King Khalid University in the Medicall \& Surgical Departements

Beacham, A. O., Linfield, K., Kinman, C. R., \& Payne-Murphy, J. (2015). The chronic illness acceptance questionnaire: Confirmatory factor analysis and prediction of perceived disability in an online chronic illness support group sample. Journal of Contextual Behavioral Science, 4(2), 96102. https://doi.org/10.1016/j.jcbs.2015.03.00

1 Bishop, D.V.M. (2016). The interface between genetics and psychology: lessons from health and clinical psychology - Department of Experimental Psychology, University of Oxford. B 282

Chaidar, W. (2011). Hemodialisa dan Prosedurnya. Retrieved from Digilib Unnes: lib.unnes.ac.id

Chen, H. J., Wang, Y. F., Qi, R., Schoepf, U. J., Varga-Szemes, A., Ball, B. D., Zhang, L. J. (2017). Altered Amygdala Resting-State Functional Connectivity in Maintenance Hemodialysis End-Stage Renal Disease Patients with Depressive Mood. Molecular Neurobiology, 54(3), 22232233.

https://doi.org/10.1007/s12035$\underline{016-9811-8}$

Christensen, A. J., Benotsch, E. G., Wiebe, J. S., \& Lawton, W. J. (1995). Coping With Treatment-Related Stress: Effects on Patient Adherence in Hemodialysis. Journal of Consulting and Clinical Psychology, 63(3), 454-459. https://doi.org/10.1037/0022 $\underline{006 X .63 .3 .454}$

Creswell, J.W., (2014). Research Design : Qualitative, Quantitative and Mixed Methods Approaches : fourth edition. Sage publications, Inc.

Creswell, Jhon W. (2016). Research Design Pendekatan Kualitatif, Kuantitatif, trimdan Mixed. Yogyakarta: Pustaka Pelajar.

Departemen Kesehatan Indonesia. (2013). Prevalensi Kesehatan Indonesia: Kementrian Kesehatan RI

Departemen Kesehatan Indonesia. (2018). Prevalensi Kesehatan Indonesia: Kementrian Kesehatan RI

Dziubek, W., Kowalska, J., Kusztal, M., Rogowski, Ł., Gołębiowski, T., 
Nikifur, M., ... Woźniewski, M. (2016). The Level of Anxiety and Depression in Dialysis Patients Undertaking Regular Physical Exercise Training - A Preliminary Study. Kidney and Blood Pressure Research, 41(1), 86-98.

https://doi.org/10.1159/000368548

Ekman, P. (2003). Emotions revealed:

Recognizing faces and feelings to improve communication and emotional life. New York, NY: Times Books.

Falvo, D. (n.d.). Medical and Psychosocial Aspects of Disability, Psychosocial Aspects. Rehabilitation Psychology.

Feroze, U., Martin, D., Reina-Patton, A., Kalantar-Zadeh, K., \& Kopple, J. D. (2010). Mental health, depression, and anxiety in patients on maintenance dialysis. Iranian Journal of Kidney Diseases, 4(3), 173-180.

Fitri, H., Hendriani, S., Zuhirah, H., \& Saldi, F. (2011), Adaptasi dan Rawat Diri Pasien Kronis Hemodialisa.

Universitas Diponegoro. 1-10.

Ghazali, Imam. 2016. Desain Penelitian Kuantitatif dan Kualitatif untuk. Ilmu Sosial. Semarang: Yoga Pratama

Gillanders, S., Wild, M., Deighan, C., \& Gillanders, D. (2008). Emotion Regulation, Affect, Psychosocial Functioning, and Well-being in Hemodialysis Patients. American Journal of Kidney Diseases, 51(4), 651662.

https://doi.org/10.1053/j.ajkd.2007. $\underline{12.023}$

Gillespie, S. M., \& Beech, A. R. (2016). Theories of Emotion Regulation. The Wiley Handbook on the Theories, Assessment and Treatment of Sexual Offending, I, 245-263. https://doi.org/10.1002/978111857 4003.w attso012
Gregg, Jennifer \& Hoffman, dkk. 2013. The Strength of Self-Acceptance.

New York: McGraw Hill

Gross, J. J. (2006). Handbook of emotion regulation (1st ed.). New York, NY, US: Guilford Press.

Gross, J., John, O. P., \& Eng, J. (1998). Three approaches to individual differences in affect regulation: Conceptualizations, measures, and findings. Handbook of emotion regulation (1sted.).

Gross, J., John, O. P., \& Eng, J. (2014). Three approaches to individual differences in affect regulation: Conceptualizations, measures, and findings. Handbook of emotion regulation (2nd ed.).

Gross, James J.; John, O. P. (2013). Emotion Regulation Questionnaire (ERQ). Journal of Personality and Social Psychology, $\quad 85, \quad 348-362$. https://doi.org/10.1037/0022 $\underline{3514.85 .2 .348}$

Harianja,N. (2010). Hubungan Kesehatan, Tubuh, dan Otak. Universitas Negeri Medan.

Hayes, S. C., \& Wilson, K. G. (1994). Acceptance and Commitment Therapy: Altering the Verbal Support for Experiential Avoidance. The Behavior Analyst, 17(2), 289-303. https://doi.org/10.1007/bf0339267 I

Hendrayani, C. I., Wirya, I. N., \& Asril, N. M. (2015). Penerapan Metode Sharing Patient pada pasien penyakit kronis dan lupus e-Journal PG PAUD Universitas Pendidikan Ganesha , 1-10.

Hofmann, S. G., Carpenter, J. K., \& Curtiss, J. (2016). Interpersonal Emotion Regulation Questionnaire (IERQ): Scale Development and Psychometric Characteristics. Cognitive Therapy and Research, 40(3), 341-356. https://doi.org/10.1007/s10608016-9756- 2 
Hyun, Ji., \& Yi, M. (2013). The influence of cognitive coping on hope, depression and satisfaction with life in hemodialysis patients. Korean Journal of Adult Nursing, 25(4), 389-399. https://doi.org/10.7475/kjan.2013.2 $\underline{5.4 .38} \underline{9}$

Ian, Sherrer. (2007). Hemodialysis and the approach of biopsychology. University of California San Fransisco. Vol. 37(5), 509-520.

INFODATIN Ginjal Indonesia. 2016. Riset Kesehatan Ginjal Indonesia: Kementrian Kesehatan RI

Isroin. (2017). Kemampuan Adaptasi, Peran, dan Konsep Diri pada Pasien Hemodialisa. Fakultas Kedokteran, Kesehatan Masyarakat, dan Keperawatan UGM, Vol.52 No.1

Kallay, E., Pop, R., \& Balazsi, R. (2009). Emotional profile and quality of life in chronic renal failure and renal transplant patients. Cognition, Brain, Behavior: An Interdisciplinary Journal, 13(3), 313-328. Retrieved from

http://ovidsp.ovid.com/ovidweb.cgi $? \mathrm{~T}=\mathrm{IS}$

$\& \mathrm{PAGE}=$ reference $\& \mathrm{D}=$ psyc $6 \& \mathrm{NE}$ $\underline{W S=N} \underline{\& A N=2009-21493-006}$

Kaplan, Atara. (1983). Psychological Problems in Kidney Failure and Their Treatment. New York: Springer Science Plenum Publishing Corporation

Kubler, Ross. E. (2014). On Death and Dying. What the Dying Have to Teach Doctors, Nurses, Clergy and Their Own Families. Elisabeth Kübler-Ross . The Quarterly Review of Biology.

https://doi.org/10.1086/406574

Law J., Garrett Z., \& Nye C. (2010). Emotion and The Approach. The Chocrane Library.5-10.
Lazarus, S. Richard. (1994). Coping with aging. Nursing Times, 93(37), 21. https://doi.org/10.1016/i.jomh.200 $\underline{8.06 .02} \underline{6}$

Mccracken, L. M., Vowles, K. E., \& Eccleston, C. (2004). Chronic Pain Acceptance Questionnaire - Revised (CPAQ-R). Pain, 107(October 2006), 159-166. Retrieved from https://www.div12.org/wp content/uploads/2015/06/ChronicPainAcceptance-Questionniare-

Revised O'Connor, S. M., Jardine, A. G., \& Millar, K. (2008). The prediction of self-care behaviors in end-stage renal disease patients using Leventhal's SelfRegulatory Model. Journal of Psychosomatic Research, 65(2), 191-200.

https://doi.org/10.1016/j.jpsychore s.2008.02.008

Oltmanns, Thomas. 2013. Psikologi Abnormal Edisi Ketujub Buku 1. Jakarta: Pustaka Pelajar.

Pop-Jordanova, N. D., \& Polenakovic, M. H. (2013). Psychological characteristics of patients treated by chronic maintenance hemodialysis. International Journal of Artificial Organs, 36(2), $\quad$ 77-86. https://doi.org/10.5301/ijao.500018 $\underline{8}$

Price, S. A. \& Wilson, L. M. 1995. Patofisiologi: Konsep Klinis ProsesProses Penyakit, Edisi 4, EGC, Jakarta.

Riset Kesehatan Dasar. 2016. RisetRiset Kesehatan Masyarakat dan Prevalensi Kesehatan Indonesia: Kementrian Kesehatan RI

Salem, M. (1995). Hypertension in the Hemodialysis Population: A Survey of 649 Patients. 461-468.

Setiawati, Farida Agus. 2016. Statistika Terapan untuk Penelitian Pendidikan dan 
Sosial. Yogyakarta: Parama Publishing

Shalhub, S., Chang, R. W., Panetta, T., Schutzer, R., Kissin, M., Hacker, R., \& Chawla, A. (2014). Hemodialysis access. Endovascular Interventions: A Case-Based Approach. https://doi.org/10.1007/978-14614-7312-1_77

Straub. (2014). Psychology in Pyhsical Approach. Stanford, USA:Cengage Learning

Sumintono, B., \& Widiharso, W. (2013). Aplikeasi Model Rasch Untuk Penelitian Ilmu-Imu Sosial. Cimahi: Trim Komunikata Publishing

Sundberg. N. D., 2007. Psikologi Klinis Perkembangan Teori, Praktik, dan Penelitian. Edisi keempat. Yogyakarta: Pustaka Pelajar.

Suwitra, K. 2006. Penyakit Ginjal Kronik, dalam: Buku Ajar Penyakit Dalam. Jakarta: Pusat Penerbitan Ilmu Penyakit Dalam FKUI

Telford, K., Kralik, D., \& Koch, T. (2006). Acceptance and denial: Implications for people adapting to chronic illness: literature review. Journal of Advanced Nursing, 55(4), 457-464. https://doi.org/10.1111/j.1365 2648.2006.03942.x

Widakdo, G., \& Besral. (2013). Efek Penyakit Kronis terhadap Gangguan Mental Emosional [Effects of Chronic Disease on Emotional Mental Disorders]. Jurnal Kesehatan Masyarakat Nasional, 7(7), 309- 316. https://doi.org/http://dx.doi.org/1 $0.21109 /$ kes mas.v7i7.29

Zalewska, A., Miniszewska, J., Chodkiewicz, J., \& Narbutt, J. (2010). Acceptance of chronic illness in psoriasis vulgaris patients. Journal of the European Academy of Dermatology and Venereology, 21(2), 235-242. https://doi.org/10.1111/j.1468 3083.2006.01912.x 